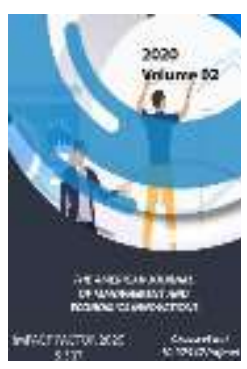

\title{
Main Directions Of The Program For Restoring The Economy Of The Republic Of Uzbekistan
}

\author{
Ulashev Kh. A.
}

PhD. D., Assoc. Samarkand Institute of Economics and Service, The Republic of Uzbekistan

Journal Website: http://usajournalshub.c om/index,php/tajmei

Copyright: Original content from this work may be used under the terms of the creative commons attributes 4.0 licence.

\section{ABSTRACT}

This article examines the state of economic reforms in Uzbekistan, priority areas of macroeconomic policy, measures to restore and continue structural changes in sectors of the economy.

\section{KEYWORDS}

Action strategy, macroeconomic stability, development concept, post-crisis recovery, reforms of market institutions.

\section{INTRODUCTION}

Economic reforms in Uzbekistan are determined by the adopted Action Strategy for the further development of the country in 20172021, which covers important aspects of economic liberalization and development of the social sphere. The strategy is aimed at increasing the competitiveness of the country's economy, creating the necessary conditions for doing business and expanding opportunities for the development of human capital. Also, measures are being taken to ensure the openness and attractiveness of Uzbekistan for the world community.

The main priority is to maintain macroeconomic stability. A key step here will be the development of the Concept of socioeconomic development of the Republic of Uzbekistan until 2030, which will formulate 
long-term goals and objectives, development priorities and methods of achieving them to ensure the sustainable economic growth of the country[1,2].

The second important development priority is the acceleration of the transition to a competitive market economy, where one of the important conditions is the implementation of reforms in the field of land use and user rights.

Another important condition is the development and deepening of financial markets, for which a Concept for the further development of the financial sector and comprehensive measures to modernize and develop the infrastructure of the financial market are being developed.

Strengthening social protection and providing services to citizens was identified as the third priority area. Pension reform is envisaged with the development of a Concept for reforming the state pension system. The system of social guarantees will also be revised. One of the important directions of reforming the social sphere will be reforming the labour market: measures are envisaged to form a wage fund in the public sector, simplify access to insurance against temporary unemployment and diversify vocational education programs.

Also, a strategy for the development of health care will be developed, which provides for wider participation of the private sector, an increase in state funding for medical services, the development and implementation of an effective mechanism for control and monitoring of the full and high-quality provision of guaranteed medical services to the population [3-5].

As part of the reform of the education sector, the national student assessment system will be modernized in cooperation with international systems such as PISA, TIMSS and PIRLS, and the teacher training curricula will be revised and brought in line with international standards.

It is envisaged to develop comprehensive measures for the development of publicprivate partnerships, as well as strategies to increase efficiency and improve the management of state-owned enterprises.

Another priority is to improve the efficiency of natural resource use, in which an important place is given to the management of water reserves and irrigation. A concept for the development of agriculture has also been developed, providing for the transition to its intensive development with the use of drip irrigation, hydroponics and other advanced agricultural technologies. All these reforms are aimed at accelerating the development of the country, improving the welfare of its population. 
Diag. 1. Stages of the Action Plans of Economic Reform

Stage 1

Stage 2

\section{- stabilization and recovery growth by the} end of 2020

\section{- continuation of systemic reforms}

Stage 1 - the expected indicators for 2020 are assessed as follows:

GDP growth - 102.2\% (initial forecast 105.5\%); industry - 103.4\% (106.5\%); agriculture - 103.3\% (104\%); investments - 101.2\% (109.3\%); services $100.1 \%$ (105.8\%); retail turnover, including catering - 103\% (105.6\%); export - 94.3\% (115.6\%).

These calculations do not include the likelihood of re-introduction of quarantine in the republic and on a global scale

Stage 2 - measures to continue systemic reforms that will ensure sustainable economic growth rates of 5.0-5.5\% from 2021 with adjustments for the consequences of the coronavirus pandemic during 2020-2021.

At the same time, taking into account the duration of the external impact and the severity of the consequences of the pandemic on certain industries and sectors of the economy (tourism, transport, and export), their exit to pre-crisis trends may go beyond 2021.

By the Resolution of the Cabinet of Ministers of the Republic of Uzbekistan dated August 29 of this year. No. 526 "On measures to restore economic growth in 2020-2021 and the continuation of systemic structural reforms in the sectors of the economy" provides for the adoption of a practical action plan for 20202021 "Road Map" to implement measures to restore and continue structural reforms of the economy.
The action plan was approved to eliminate the negative impact of the coronavirus pandemic on the socio-economic development of the Republic of Uzbekistan, restore investment and foreign economic activity of business entities, and create conditions for further deepening economic reforms.

To restore and continue structural changes in the sectors of the economy, it is necessary:

- Implement macroeconomic policies aimed at supporting the development of key sectors of the economy in 2020 and ensuring sustainable economic growth at the level of $5.0-5.5 \%$ from 2021, continue reforming market institutions;

- Continue further reforming the banking system in the post-crisis period, aimed at transforming banks and implementing measures to ensure the efficiency of the quality of banking services;

- Stimulate domestic demand and reduce poverty by providing employment and increasing incomes, expanding program measures to provide financial support to start-up entrepreneurs;

- Improve industrial and competition policies based on stimulating domestic demand for national products, develop cooperative relations, continue reforms at enterprises of strategic industries;

- To intensify investment processes by expanding internal resources to stimulate the participation of local investors in the implementation of projects to finance 
infrastructure projects and create valueadded production "chains";

- Financially develop exporting enterprises through support, including increased use of modern means of trade finance, stimulating foreign economic activity and support by encouraging trade organizations to expand the supply of local products to new export markets;

- Expand the participation of private entrepreneurship in the public procurement system, increase the convenience of doing business and the competitive environment through the development of small industrial zones in the region and the allocation of additional financial resources for the transfer of transport infrastructure facilities, the development of private entrepreneurship;

- Develop a network of trade organizations that provide comprehensive services to the population in the regions, gradually selling state assets, attract private investment in the development of telecommunications networks in rural areas, as well as highspeed Internet access for all social institutions in rural areas and settlements in 2021, support service businesses and digital development;

An important condition for post-crisis recovery and sustainable economic development in the medium and long term is the formation of the foundations for curbing the growth of external debt, consistent improvement of conditions for increasing private and foreign direct investment. This necessitates a consistent continuation of the initiated course of reforms to liberalize the economy (including the energy market), develop a competitive environment, improve the business climate, and reduce the share of the public sector in the economy, which will contribute to a steady increase in the inflow of foreign investment in the medium term.

The key measures in the field of macroeconomic policy and the reform of market institutions in our country are identified:

- Curbing the growth of external debt by tight control over the efficiency of the use of borrowed funds. This requires retention of fiscal expenditures, all-round stimulation of private investment. A wellthought-out plan of medium-term measures is needed to prevent in subsequent years from exceeding the legislatively established maximum volumes of newly signed agreements on attracting external government borrowing, planning budget expenditures at an acceptable level and tightening control over their use;

- Effective use of external borrowings, directing them mainly to finance the budget deficit and infrastructure projects and social facilities, which affects economic growth, ensuring employment and reducing poverty in the medium and long term;

- Optimization of investment costs of the state by tightening the criteria for selecting a project at the feasibility study stage, making adjustments and refusing to implement investment projects that have lost their relevance due to changes in market conditions, cost and timing of implementation, as well as monitoring the implementation of investment projects and efficiency after their commissioning, expanding the use of private investments and project financing instruments, developing public-private partnerships and the stock market;

- Completion of work on optimization of customs privileges;

- Improvement of industrial and competition policy. Development and adoption of an Industrial Policy Strategy for the medium term with the identification of new development drivers to attract foreign direct investment and the concentration of financing "growth points", stimulating a consistent increase in the participation of domestic enterprises in international value 
chains, increasing competitiveness in export markets, completing the reform process of state-owned enterprises;

- Continuation of the reform of the agricultural sector by eliminating administrative interference in the economic activities of agricultural producers, introducing market mechanisms for pricing, the movement of funds, improving the mechanism of mortgage turnover of land, stimulating the creation of value chains in agriculture;

- Growth of labour productivity in the economy and each industry due to the optimization of production costs, the introduction of modern technologies, the digitalization of production processes, the ultimate goal of which is to increase the specific output per employee and his wages, increase the international competitiveness of domestic products;

\section{REFERENCES}

1. Decree of the President of UZB "Concept of integrated socioeconomic development of the Republic of Uzbekistan until 2030", ID8839.

2. News of Uzbekistan today: nuz.uz electronic newspaper. (n.d.). News of Uzbekistan Today: Nuz.Uz. Retrieved December 23, 2020, from https://nuz.uz.

3. Davlat Statistika Qo`mitasi. (n.d.). O’zbekiston Respublikasi Davlat Statistika Qo`mitasi. Stat.Uz. Retrieved December 23, 2020, from https://www.stat.uz/uz/

4. Hakimova, S., Habijonov, S., \& Hojaev, A. (2018). Statistical prognosis of the production of fruits and vegetables grown by farmers in the Fergana region. Bulletin of Science and Practice.

5. Khojaev, A. S., \& Akramova, N. M. (2017). The ways of development and statistic analysis of farmers'activities specialized in fruit-vegetables production in the ferghana region. In Economics, management and law: innovative problem solving (pp. 45-47). 